\title{
Biodegradation of omethoate by Bacillus sp. YB-10: optimization of culture conditions and degradation characteristics
}

\author{
Riqiang $\mathrm{Li}^{{ }^{\dagger}}$, Jianxing $\mathrm{Wang}^{1^{\dagger}}$, Songhui $\mathrm{Li}^{2}$ \\ ${ }^{1}$ College of Environmental \& Resources Sciences, Shanxi University, Taiyuan 030006, China \\ ${ }^{2}$ Weihai Water Group Co., Ltd., Weihai 264200, China
}

\begin{abstract}
Omethoate is an acute organophosphorus pesticide which is widely used. It presents a high pollution potential and health risk nowadays. In this study, Bacillus sp. YB-10, which was isolated from the activated sludge of a pharmaceutical wastewater treatment plant, was used for degrading omethoate. The culture conditions and degradation characteristics were investigated. Results showed that the Bacillus sp. YB-10 could degrade omethoate through co-metabolism. The optimal carbon and nitrogen sources were glucose and $\mathrm{NH}_{4} \mathrm{NO}_{3}$, respectively. Response surface methodology (RSM) results showed that the most appropriate nutrition ratio of C:N:P was 3:1:1 when degrading 1,000 mg/L of omethoate. Omethoate degradation kinetics could be described by a first-order rate equation. The optimal degradation conditions were $\mathrm{pH}$ of 7.0 , temperature of $30^{\circ} \mathrm{C}$, initial bacteria concentration of $0.25 \%$, rotation speed of $150 \mathrm{r} / \mathrm{min}$. Under the optimal conditions, the degradation rate reached $77.24 \%$ within $5 \mathrm{~d}$ by the Bacillus sp. YB-10 when the initial omethoate concentration was $1,000 \mathrm{mg} / \mathrm{L}$.
\end{abstract}

Keywords: Bacillus sp. YB-10, Biodegradation, Co-metabolism, Omethoate, Organophosphorus pesticide

\section{Introduction}

Omethoate (O,O-dimethyl-S-methylcarbamoylmethylthiophosphate, $\mathrm{C}_{5} \mathrm{H}_{12} \mathrm{NO}_{4} \mathrm{PS}$ ) is one of the acute organophosphorus pesticides that are widely used to prevent, destroy, repel, or mitigate agricultural and domestic insects in developing countries [1-4]. For example, 8,000 tons of omethoate are applied to agricultural crops annually in China [5]. Actually, only a small percent of them reaches the target pest; the rest spreads to the ecosystem through water, soil, and food [6]. Therefore, omethoate is found throughout the environment nowadays [7]. It was reported that omethoate had clear mutagenic potential and allergic disorder [5], and was hardly biodegradable by the environment naturally in short time. Therefore, omethoate presents a serious pollution potential and health risk to the environment and human [8, 9]. It is very important to find a feasible way to alleviate the contamination of omethoate in wastewater, soil and groundwater.

In view of the bioresistant of omethoate, some researchers tried to remove it through physicochemical methods, such as adsorption [10], catalytic ozonation [11, 12], phase surface discharge plasma [13] and photocatalytic [14]. Xiao et al. [15] reported that omethoate removal efficiency could achieve $72.1 \%$ using a new adsorbent of PBPC (which rice bran protein was cross-linked with eerie ammonium nitrate). Some researchers developed novel photocatalyst for efficient destruction of organic contaminations in water [16, 17], such as $\mathrm{Dy}_{2} \mathrm{Ce}_{2} \mathrm{O}_{7}$ ceramic nanostructures [18] and silver tungstate nanostructures [19]. All these nanomaterials revealed excellent photocatalytic efficiency for the environmental remediation. The physicochemical methods had perfect removal efficiency; however, most of them were limited by application, operation or cost.

Biodegradation of pesticides by microorganisms has excellent advantages such as simpler operation and less cost than physical and chemical approach [20]. Thus it was considered to be one of the most effective ways for remediation of pesticide contamination [3]. Cheng et al. [21] reported that multifunctional constructed wetland could remove omethoate completely; however, the omethoate concentration in the influent was much low $(60 \mu \mathrm{g} / \mathrm{L})$. The key of pesticides biodegradation was isolating the bacteria strains which have high degradation ability. In recent year, various microbes were isolated for biodegradation of organophosphorus pesticides, including the species of Arthrobacter, Burkholderia,

Received May 13, 2020 Accepted August 24, 2020

${ }^{\dagger}$ Corresponding author

Email: liriqiang@sxu.edu.cn, wangjx23@163.com Tel: +863517010600 Fax: +863517010600 mits unrestricted non-commercial use, distribution, and
medium, provided the original work is properly cited.

Copyright (C) 2021 Korean Society of Environmental Engineers 
Enterobacter, Flavobacterium, Pseudomonas, Serratia, Sphingobium, Bacillus, Aspergillus, Trichoderma, Streptomyces, Brevibacterium [7, 22-25]. However, the researches of omethoate biodegradation were very limited.

The microbes which could degrade omethoate in literatures were also lacking. The reported omethoate-degrading microbes mainly belonged to fungal species. Tao et al. [3] had isolated an Aspergillus niger strain to degrade the omethoate. Meng et al. [8] screened out a strain of Aspergillus spp. F1 which could degrade omethoate effectively. Zhao et al. [26] showed fungus strain of Penicillium oxalicum could degrade omethoate using glucose as carbon source. As lots of bacteria could degrade organophosphorus pesticides, there might be certain bacteria strains which had high degradation ability of omethoate. Li et al. [6] found six Lactobacillus plantatum strains possessing high capacity of degrading omethoate. Zhang et al. [27] isolated a Paracoccus sp. strain FLN-7 which could hydrolyze omethoate through amide bond cleavage. In addition to these researches, omethoate degradation bacteria were rarely reported. Furthermore, various studies showed that the ability for organophosphorus pesticides biodegradation was affected by external conditions including nutrients, temperature, $\mathrm{pH}$, etc [26, 28]. Therefore, the culture conditions and degradation characteristics should also be definited in order to achieve perfect degradation effectivity.

We have isolated a strain of Bacillus sp. YB-10 from the activated sludge of omethoate wastewater treatment plant and used it for biodegrading omethoate. The objective of this study was to investigate the optimal culture conditions through single-factor experiments and response surface methodology (RSM); and determine the omethoate degradation characteristics and conditions of Bacillus sp. YB-10. In addition, kinetics of omethoate degradation would also be investigated.

\section{Materials and Methods}

\subsection{Chemicals and Media}

$40 \%$ omethoate (molecular formula: $\mathrm{C}_{5} \mathrm{H}_{12} \mathrm{NO}_{4} \mathrm{PS}$ ) emulsifiable concentrate was used in this study. The chemical structure of omethoate was described as Fig. S1.

The enrichment medium (EM) comprised (g/L) [29]: peptone, 10.0; $\mathrm{NaCl}, 1.0 ; \mathrm{KH}_{2} \mathrm{PO}_{4}$, 1.0; glucose, 1.0. The mineral salt medium (MSM) was composed of (g/L): $\mathrm{NaNO}_{3}, 2.0 ; \mathrm{KCl}, 0.5 ; \mathrm{MgSO}_{4} \cdot 7 \mathrm{H}_{2} \mathrm{O}$, $0.5 ; \mathrm{MnSO}_{4}, 0.02 ; \mathrm{CaCl}_{2}, 0.04$. The mineral salt medium with glucose was composed of MSM and $1.5 \mathrm{~g}$ of glucose. The beef extract peptone medium was composed of $(\mathrm{g} / \mathrm{L})$ [30]: beef extract, 3.0; peptone, 10.0; $\mathrm{NaCl}, 5.0$. To prepare solid medium, $2 \%$ of agar was added in the liquid medium. All media had their $\mathrm{pH}$ maintained at 7.0-7.5 and were sterilized under $0.1 \mathrm{MPa}$ for $30 \mathrm{~min}$. When the media were cooled to $50^{\circ} \mathrm{C}$, certain concentration of omethoate were added in and mixed.

\subsection{Microorganism}

A Bacillus sp. strain was isolated in our laboratory from the activated sludge sample of the wastewater treatment plant in a pharmaceutical industry located in Henan Province, China. During enrichment cultures, $10 \mathrm{~mL}$ of activated sludge suspension (20\%) was added in $90 \mathrm{~mL}$ of $\mathrm{EM}$ which contained $200 \mathrm{mg} / \mathrm{L}$ of omethoate, and then incubated at $30^{\circ} \mathrm{C}$ in a rotary shaker at $150 \mathrm{rpm}$ for $5 \mathrm{~d}$. Then $10 \%$ of the enriched activated sludge was added to EM with certain concentration of omethoate and incubated under the same conditions. The enrichment step was repeated for 4 times and omethoate concentration was 500, $(1,000),(2,000)$ and 5,000 mg/L, respectively. Then the organisms were separated on beef extract peptone medium using plate smearing method. The strain was isolated and purified by inoculating on beef extract peptone medium and incubated for $2 \mathrm{~d}$. The bacterial strain was preliminarily characterized and identified as Bacillus sp. YB-10 on the basis of morphological, physiological, biochemical and carbon source utilization characteristics.

Before use, the selected strains were incubated in beef extract peptone medium and agitated at $30^{\circ} \mathrm{C}$ and $150 \mathrm{rpm}$ for $24 \mathrm{~h}$, followed by centrifugation at 5,000 r/min for $20 \mathrm{~min}$. The precipitates were washed with sterile water for 3 times. The cells were diluted with sterile water to obtain a bacterial suspension with $0.25 \mathrm{~g} / \mathrm{mL}$ (which $0.25 \mathrm{~g}$ wet bacteria suspended in $1 \mathrm{~mL}$ of sterile distilled water) for the omethoate degradation test.

\subsection{Optimization of Culture Conditions}

\subsubsection{Single-factor experiments}

Effect of different carbon and nitrogen sources, and the nutrition concentrations on Bacillus sp. YB-10 growth and omethoate degradation were carried out through single-factor experiments. The details and steps of the tests were described as follows:

(1) Effect of different carbon sources: The carbon sources included starch, glucose, mannitol, sorbitol, maltose, sucrose, lactose, fructose, methionine, and threonin. $1.5 \mathrm{~g} / \mathrm{L}$ of each carbon source was added in $100 \mathrm{~mL}$ of MSM which contained $1,000 \mathrm{mg} / \mathrm{L}$ of omethoate.

(2) Effects of carbon source concentration: Certain concentration of optimal carbon source determined by step (1) was added in the same medium to confirm the optimal concentration.

(3) Effect of different nitrogen sources: The nitrogen sources included $\mathrm{NH}_{4} \mathrm{Cl}, \mathrm{NH}_{4} \mathrm{NO}_{3}, \mathrm{KNO}_{3}$, $\left(\mathrm{NH}_{4}\right)_{2} \mathrm{SO}_{4}$, beef extract, peptone and yeast. $0.5 \mathrm{~g} / \mathrm{L}$ of each nitrogen source was added in $100 \mathrm{~mL}$ of MSM to replace the original nitrogen sources of $\mathrm{NaNO}_{3}$. In addition, the used MSM contained 1,000 mg/L of omethoate and optimal carbon source according to the results of above tests.

(4) Effects of nitrogen source concentration: Certain concentration of optimal nitrogen source determined by step (3) was added in the same medium to investigate the optimal concentration.

(5) Effects of phosphorus source concentration: The phosphorus source used in this study was $\mathrm{KH}_{2} \mathrm{PO}_{4}$. Certain concentration of $\mathrm{KH}_{2} \mathrm{PO}_{4}(0-3 \mathrm{~g} / \mathrm{L})$ was added in $100 \mathrm{~mL}$ of MSM. The MSM contained 1,000 mg/L of omethoate and optimal carbon and nitrogen source according to the results of above tests.

During each experiment, $0.25 \mathrm{~mL}$ of bacterial suspension was inoculated to $100 \mathrm{~mL}$ of medium at $30^{\circ} \mathrm{C}$ and $150 \mathrm{r} / \mathrm{min}$ for 5 $\mathrm{d}$. Then the biomass and omethoate concentration were measured. All the experiments were carried out in triplicate. 


\subsubsection{Response surface methodology (RSM)}

The concentrations of carbon, nitrogen and phosphorous sources were identified by experiment as variables with significant effects on omethoate degradation by the Bacillus sp. YB-10. The experimental design chosen for this study was that of Box- Behnken, which needed relatively a few experimental combinations of the variables [31]. The experimental design and statistical analysis were done with SAS software (SAS Institute, Cary, NC, USA). In this study, the variable factors with the coded and actual values were given in Table 1 according to the single-factor experiments results.

Table 1. Levels and Codes of the Box-Behnken Experimental Design

\begin{tabular}{lccc}
\hline Code & $\begin{array}{c}\mathbf{X}_{\mathbf{1}} \\
\left(\text { Glucose } / \mathbf{g} \cdot \mathbf{L}^{-\mathbf{1}}\right)\end{array}$ & $\begin{array}{c}\mathbf{X}_{\mathbf{2}} \\
\left(\mathbf{N H}_{\mathbf{4}} \mathbf{N O}_{\mathbf{3}} / \mathbf{g} \cdot \mathbf{L}^{-\mathbf{1}}\right)\end{array}$ & $\begin{array}{c}\mathbf{X}_{\mathbf{3}} \\
\left(\mathbf{K H}_{\mathbf{2}} \mathbf{P O} \mathbf{O}_{\mathbf{4}} / \mathbf{g} \cdot \mathbf{L}^{-\mathbf{1}}\right)\end{array}$ \\
\hline-1 & 1.2 & 0.25 & 0.5 \\
0 & 1.5 & 0.5 & 1.0 \\
1 & 1.8 & 0.75 & 1.5 \\
\hline
\end{tabular}

\subsection{Effect of Omethoate Concentration and Omethoate Degradation Modeling}

To investigate the effect of omethoate concentration, $0.25 \mathrm{~mL}$ of the Bacillus sp. YB-10 bacterial suspension was incubated in 100 $\mathrm{mL}$ of the optimal medium with omethoate concentration of 200-5,000 $\mathrm{mg} / \mathrm{L}$ and reacted at $30^{\circ} \mathrm{C}, 150 \mathrm{r} / \mathrm{min}$ for $7 \mathrm{~d}$. The omethoate degradation rate was measured every day.

First order kinetics was used to describe the biodegradation of omethoate under concentration of 200-5,000 mg/L. The first-order rate equation could be described as Eq. (1) [3]:

$$
[C]=\left[\mathrm{C}_{0}\right] \mathrm{e}^{-K t}
$$

Where $C$ is the concentration of omethoate, $C_{0}$ is the initial concentration of omethoate, $K$ is the degradation constant, and $t$ is time.

When $[C]=0.5\left[C_{0}\right]$, the half-time for omethoate degradation is $t_{1 / 2}=\ln 2 / K$.

\subsection{Effect of Degradation Conditions}

To investigate the effect of degradation conditions, different $\mathrm{pH}$ (5.0-8.0), temperature $\left(15^{\circ} \mathrm{C}-35^{\circ} \mathrm{C}\right)$, initial bacteria concentration (0.1\%-0.5\%, which $0.1-0.5 \mathrm{~mL}$ of bacterial suspension were added in $100 \mathrm{~mL}$ of medium), and rotation speed (100-250 r/min) were chosen in this study. For each experiment, the bacterial suspension was incubated in the optimal medium and degraded for $5 \mathrm{~d}$. The initial omethoate concentrations of all the experiments were 1,000 mg/L. Each experiment was repeated 3 times.

\subsection{Analysis Methods}

Gas chromatograph (GC-7900 Techcomp, China) was used to measure the concentration of omethoate. The chromatography analysis was performed using HP-1 $30 \mathrm{~m} \times 0.53 \mathrm{~mm} \times 1.5 \mu \mathrm{m}$ chromatographic column. The temperature programming comprised a starting temperature of $160^{\circ} \mathrm{C}$ for $3 \mathrm{~min}$ that increased from $160^{\circ} \mathrm{C}$ to $250^{\circ} \mathrm{C}$ at a rate of $15^{\circ} \mathrm{C} / \mathrm{min}$. The temperature was held for 12 $\min$ at $250^{\circ} \mathrm{C}$ to complete the run. The sample size used for analysis was $1 \mu \mathrm{L}$. The carrier flow was $\mathrm{N}_{2}$.

The bacteria biomass was measured by determining the optical density at $600 \mathrm{~nm}\left(\mathrm{OD}_{600}\right)$ using a spectrophotometer (TU-1800S, PERSEE, China) [32].

\section{Results and Discussion}

\subsection{Optimization of Culture Condition for the Bacillus sp. YB-10 Strain}

\subsubsection{Effects of carbon source and concentration}

Carbon source is an essential energy material for microbial growth, reproduction and movement [33]. It could also form the cells of microbial. The effects of different carbon sources on strain growth and omethoate degradation were shown in Fig. 1(a).

As shown in Fig. 1(a), glucose was the optimal carbon source for Bacillus sp. YB-10, which the $\mathrm{OD}_{600}$ reached 0.884, and the omethoate degradation rate reached $75.81 \%$. This result was consistent with Meyer et al.'s study [33], which stated glucose was the preferred carbon source for Bacillus subtilis. Maltose and sucrose were the second proper carbon sources in this study. There were poor strain growth and omethoate degradation of fructose and lactose. Ren et al. [34] also reported that fructose exhibited lower biomass than glucose for Scenedesmus sp. strain R-16, which was in agreement with this study. It also showed that starch had no promotes for strain growth. In this work, glucose is a kind of monosaccharides; therefore, it can be used by microbes easily for its simple structures. However, disaccharides such as maltose, sucrose and lactose have complex structures comparing to monosaccharides; hence, they cannot convert as energy efficiently by bacteria [35].

Fig. 1(a) also shows that Bacillus sp. YB-10 could grow with sugar alcohols such as mannitol and sorbitol; however, the omethoate degradation efficiency was poor. Methionine and threonin could neither be used by Bacillus sp. YB-10, nor promoted omethoate degradation. This was because that some amino acids could only be used as energy sources by anaerobic microbes when lacking of carbon source [23]. Consequently, glucose was chosen as the optimal carbon source for the Bacillus sp. YB-10.

Then the effects of glucose concentration were investigated. Results were shown in Fig. 1(b). It was clear that both the $\mathrm{OD}_{600}$ and omethoate degradation rate were 0 when no glucose was added. This implied that stain of Bacillus sp. YB-10 could not grow and degrade omethoate when the omethoate was used as sole carbon source. Therefore, it suggested that the Bacillus sp. YB-10 degraded omethoate through co-metabolism. When the glucose concentration increase as $0,0.3,0.9,1.2,1.5,1.8,2.5$ and $3 \mathrm{~g} / \mathrm{L}$, the biomass increased obviously and then achieved a stable level. The omethoate degradation rate increased when the glucose concentration increased from 0 to $1.5 \mathrm{~g} / \mathrm{L}$; however, when the glucose concentration was $>1.5 \mathrm{~g} / \mathrm{L}$, the degradation rate decreased. This result showed that when the omethoate concentration was constant, it has a proper ratio of glucose concentration in the co-metabolism system. When the glucose concentration was low, there were not enough carbon sources for the bacteria. However, high concentration of glucose would induce the bacteria to give up using omethoate. In this 

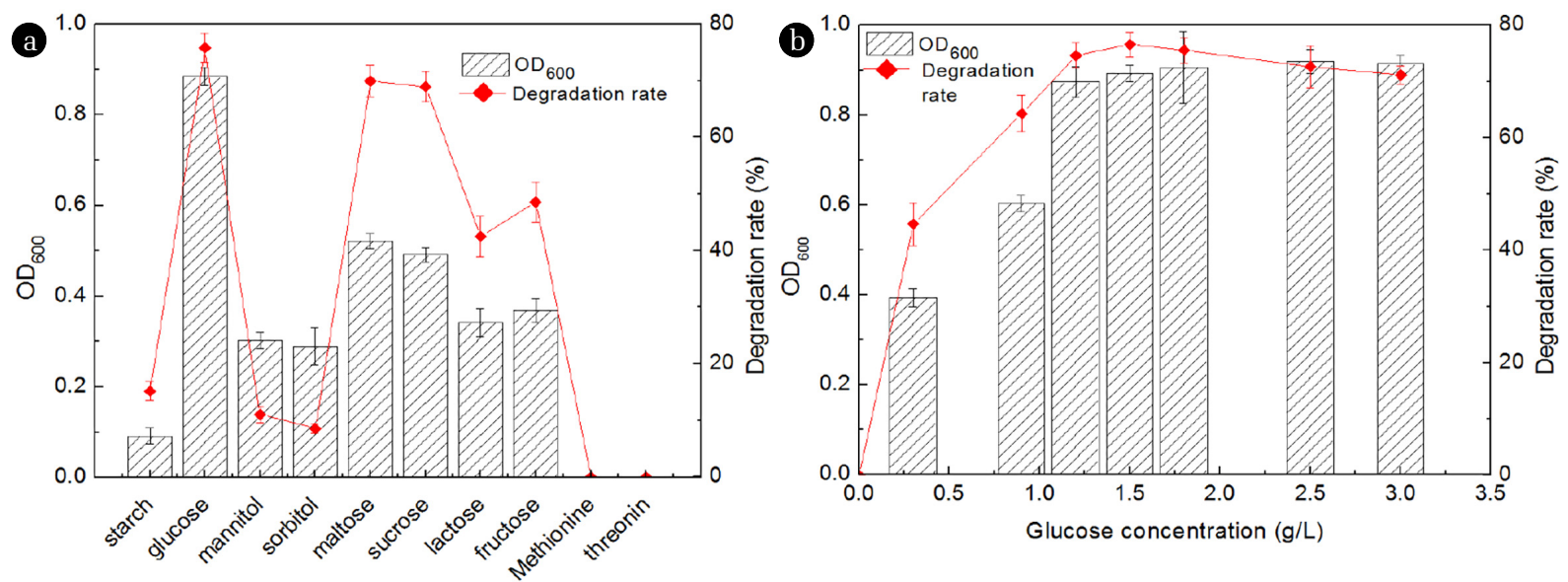

Fig. 1. The effect of carbon source and concentration on Bacillus sp. YB-10 growth and omethoate degradation. (omethoate concentration: 1,000 mg/L, $\mathrm{pH}=7.0,30^{\circ} \mathrm{C}$, initial bacteria concentration: $0.25 \%$, rotation speed: $150 \mathrm{r} / \mathrm{min}$, degradation time: $5 \mathrm{~d}$ )

study, the glucose concentration was determined at $1.5 \mathrm{~g} / \mathrm{L}$ when the omethoate concentration was $1,000 \mathrm{mg} / \mathrm{L}$.

\subsubsection{Effects of nitrogen source and concentration}

The nitrogen source material in medium was mainly used to synthesize the nitrogenous substances such as protein, nucleic acid, enzymes, and kinds of primary and secondary metabolites in cell. Lacks of nitrogen could restrict the growth of microbes [35]. The effects of different nitrogen sources on strain growth and omethoate degradation were shown in Fig. 2(a).

As shown in Fig. 2(a), the Bacillus sp. YB-10 could grow in medium contained different nitrogen sources; however, the utilization effectivities were much different. The strain growth and omethoate degradation revealed the best effectivities when $\mathrm{NH}_{4} \mathrm{NO}_{3}$ was used as nitrogen source. The following were $\left(\mathrm{NH}_{4}\right)_{2} \mathrm{SO}_{4}, \mathrm{NH}_{4} \mathrm{Cl}$, and $\mathrm{KNO}_{3}$, which the degradation rates were $74.55 \%, 66.84 \%$ and $62.13 \%$, respectively. There were poor utilizations of yeast, peptone, and beef extract, which the degradation rates were about $50 \%$. These results illustrated that inorganic nitrogen were more con- ducive than organic nitrogen for bacteria growth and omethoate degradation. Abundant organic nitrogen might restrict the use of omethoate, which correspondingly decreased the degradation rate [36]. Among the four inorganic nitrogen sources, $\mathrm{NH}_{4} \mathrm{NO}_{3}$ has the best degradation effectivity. This result was consistent with previous study [37]. The reason for this phenomenon might be that both $\mathrm{NH}_{4}{ }^{+}$and $\mathrm{NO}_{3}{ }^{-}$could provide nitrogen for using. In addition, the $\mathrm{NH}_{4}{ }^{+}$in $\left(\mathrm{NH}_{4}\right)_{2} \mathrm{SO}_{4}$ and $\mathrm{NH}_{4} \mathrm{Cl}$ was more helpful than the $\mathrm{NO}_{3}{ }^{-}$ in $\mathrm{KNO}_{3}$, which was due to the $\mathrm{NO}_{3}^{-}$could not be used unless it was reduced to ammonia. In this study, $\mathrm{NH}_{4} \mathrm{NO}_{3}$ was chosen as the most appropriate nitrogen source.

Effects of $\mathrm{NH}_{4} \mathrm{NO}_{3}$ concentration were investigated subsequently and results were shown in Fig. 2(b). It was clear that the effects of $\mathrm{NH}_{4} \mathrm{NO}_{3}$ concentration were obvious. When the $\mathrm{NH}_{4} \mathrm{NO}_{3}$ concentration was 0 , the bacteria could still grow and degrade omethoate. This phenomenon suggested that Bacillus sp. YB-10 could use the omethoate as the sole nitrogen source. The $\mathrm{OD}_{600}$ of the Bacillus sp. YB-10 and omethoate degradation rate increased evidently when $\mathrm{NH}_{4} \mathrm{NO}_{3}$ concentration was $<0.5 \mathrm{~g} / \mathrm{L}$. Then the growth of Bacillus
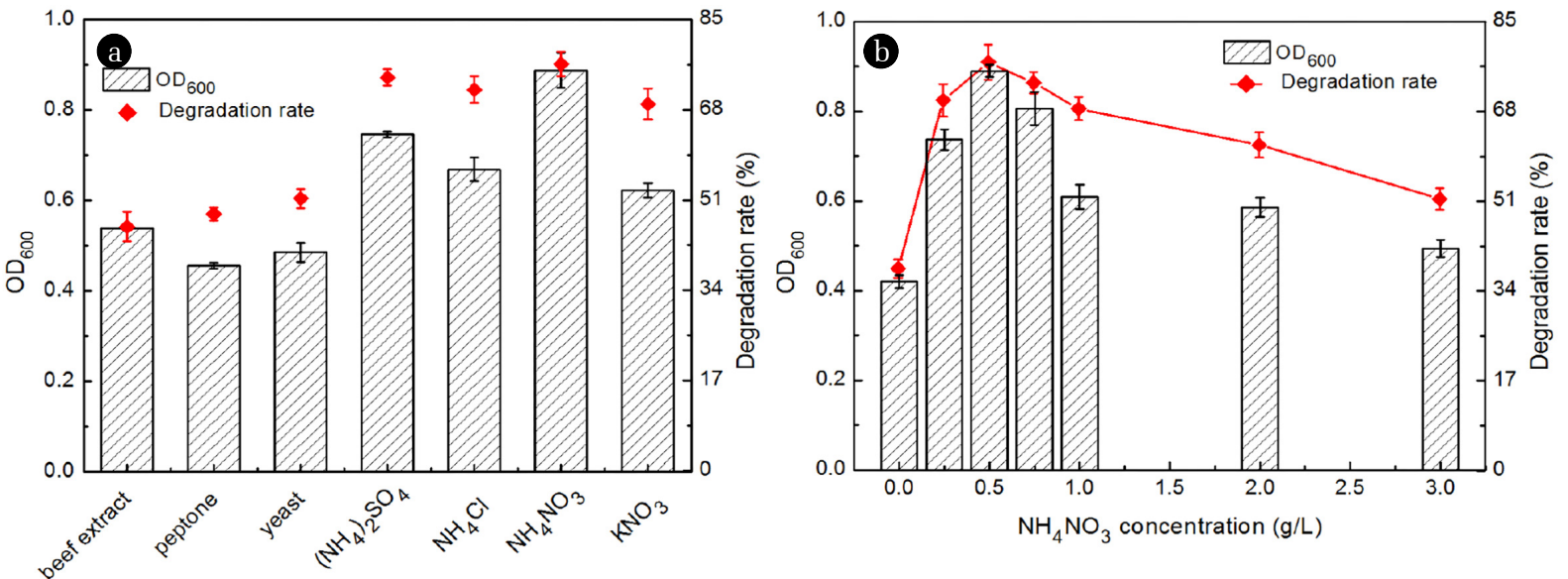

Fig. 2. The effect of nitrogen source and concentration on Bacillus sp. YB-10 growth and omethoate degradation. (omethoate concentration: $1,000 \mathrm{mg} / \mathrm{L}, \mathrm{pH}=7.0,30^{\circ} \mathrm{C}$, initial bacteria concentration: $0.25 \%$, rotation speed: $150 \mathrm{r} / \mathrm{min}$, degradation time: $5 \mathrm{~d}$ ) 
Table 3. Analysis of Variance (ANOVA) for the Regressive Model

\begin{tabular}{|c|c|c|c|c|c|c|}
\hline Error Source & $D F$ & SS & MS & $\boldsymbol{F}$ & $P r>F$ & Significant \\
\hline $\mathrm{X}_{1}$ & 1 & 14.1778 & 14.1778 & 24.1955 & 0.0044 & $* *$ \\
\hline $\mathrm{X}_{2}$ & 1 & 14.6341 & 14.6341 & 24.9741 & 0.0041 & ** \\
\hline $\mathrm{X}_{3}$ & 1 & 7.9800 & 7.9800 & 13.6185 & 0.0141 & * \\
\hline $\mathrm{X}_{1} \mathrm{X}_{1}$ & 1 & 70.9830 & 70.9830 & 121.1380 & 0.0001 & ** \\
\hline $\mathrm{X}_{1} \mathrm{X}_{2}$ & 1 & 0.0256 & 0.0256 & 0.0437 & 0.8427 & \\
\hline $\mathrm{X}_{1} \mathrm{X}_{3}$ & 1 & 1.7292 & 1.7292 & 2.9511 & 0.1465 & \\
\hline $\mathrm{X}_{2} \mathrm{X}_{2}$ & 1 & 78.0302 & 78.0302 & 133.1645 & 0.0001 & $* *$ \\
\hline $\mathrm{X}_{2} \mathrm{X}_{3}$ & 1 & 1.4641 & 1.4641 & 2.4986 & 0.1748 & \\
\hline $\mathrm{X}_{3} \mathrm{X}_{3}$ & 1 & 112.8971 & 112.8971 & 192.6675 & 0.0001 & ** \\
\hline Linear & 9 & 36.7919 & 12.2640 & 20.9294 & 0.0029 & \\
\hline Quadratic & 3 & 227.5825 & 75.8608 & 129.4623 & 0.0001 & \\
\hline Cross Product & 3 & 3.2189 & 1.0730 & 1.8311 & 0.2586 & \\
\hline Model & 3 & 267.5933 & 29.7326 & 50.7410 & 0.0002 & \\
\hline Error & 5 & 2.9298 & 0.5860 & & & \\
\hline Lack of fit & 3 & 2.9234 & 0.9745 & 301.3789 & 0.0033 & \\
\hline Pure Error & 2 & 0.0065 & 0.0032 & & & \\
\hline Total & 14 & 270.5231 & & & & \\
\hline
\end{tabular}

SS, sum of squares; DF, degree of freedom; MS, mean square.

"Significant $(\mathrm{P}<0.05),{ }^{* *}$ Highly significant $(\mathrm{P}<0.01)$.

sp. YB-10 and omethoate degradation rate decreased as the $\mathrm{NH}_{4} \mathrm{NO}_{3}$ concentration keeping increase. This was because that the ratio of C:N is an important factor during the biodegradation of pesticides by bacteria. High concentration of $\mathrm{NH}_{4} \mathrm{NO}_{3}$ would decrease C:N ratio, which correspondingly restricted the growth of bacteria [36, 37].

\subsubsection{Effects of $\mathrm{KH}_{2} \mathrm{PO}_{4}$ concentration}

Phosphorous could improve the growth of microbial cells. However, when the concentration was too high, it could restrain the secondary metabolism of some microbes. The effects of $\mathrm{KH}_{2} \mathrm{PO}_{4}$ concentration on strain growth and omethoate degradation were shown in Fig. 3.

As shown in Fig. 3, the effect of $\mathrm{KH}_{2} \mathrm{PO}_{4}$ concentration was similar to $\mathrm{NH}_{4} \mathrm{NO}_{3}$ concentration. When the $\mathrm{KH}_{2} \mathrm{PO}_{4}$ concentration was 0 , the bacteria could also grow and degrade omethoate. Thus it implied that Bacillus sp. YB-10 could use the omethoate as the sole phosphorous source. The $\mathrm{OD}_{600}$ of the Bacillus sp. YB-10 and omethoate degradation rate increased with $\mathrm{KH}_{2} \mathrm{PO}_{4}$ concentration when $\mathrm{KH}_{2} \mathrm{PO}_{4}$ concentration was $<1.0 \mathrm{~g} / \mathrm{L}$. When $\mathrm{KH}_{2} \mathrm{PO}_{4}$ concentration was $1.0 \mathrm{~g} / \mathrm{L}$, the $\mathrm{OD}_{600}$ of the $\mathrm{YB}-10$ and omethoate degradation rate reached the highest lever, i.e. 0.896 and $77.38 \%$ after 5 d, respectively. In addition, the $\mathrm{OD}_{600}$ of the $\mathrm{YB}-10$ and omethoate degradation rate declined when $\mathrm{KH}_{2} \mathrm{PO}_{4}$ concentration was $>1.0 \mathrm{~g} / \mathrm{L}$. Prakash et al. [37] also reported that higher concentration of phosphate would decrease the curdlan production by Bacillus cereus PR3.

As mentioned above, Bacillus sp. YB-10 could use the omethoate as the sole nitrogen source and phosphorous source, whereas not as sole carbon source. Adding certain amount of nitrogen and phosphorous sources could promote bacteria growth and omethoate degradation; however, higher content of nitrogen and phosphorous sources could decrease the degradation rates.

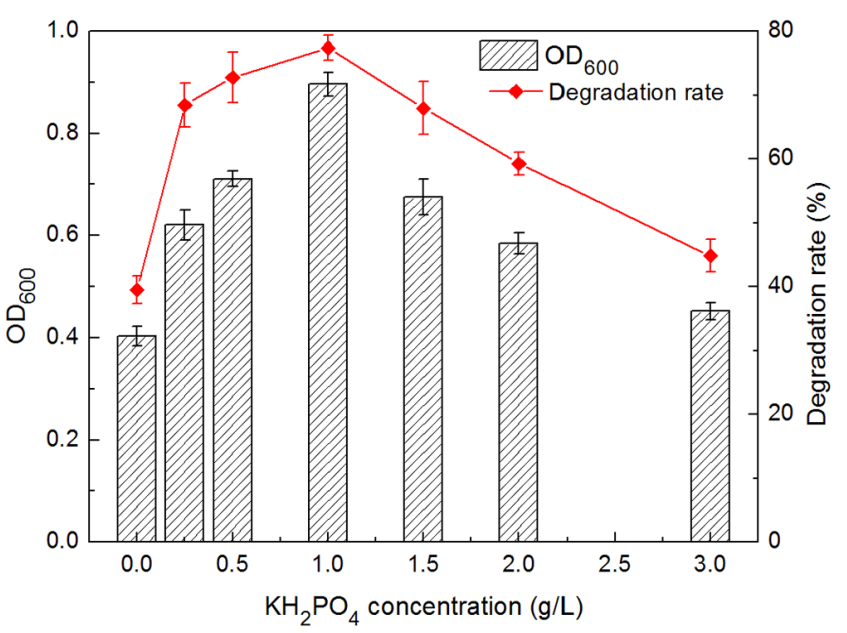

Fig. 3. The effect of $\mathrm{KH}_{2} \mathrm{PO}_{4}$ concentration on Bacillus sp.YB-10 growth and omethoate degradation. (omethoate concentration: 1,000 $\mathrm{mg} / \mathrm{L}, \mathrm{pH}=7.0,30^{\circ} \mathrm{C}$, initial bacteria concentration: $0.25 \%$, rotation speed: $150 \mathrm{r} / \mathrm{min}$, degradation time: $5 \mathrm{~d}$ )

\subsubsection{Response surface methodology (RSM) results}

The Box-behnken experimental design was used to determine the composition of medium on the basis of single-factor experiments above. Concentrations of glucose, $\mathrm{NH}_{4} \mathrm{NO}_{3}$ and $\mathrm{KH}_{2} \mathrm{PO}_{4}$ were defined as variables according to Table 1, and results were shown in Table 2. The second-order response surface model fitting results were given in Table 3 in the form of ANOVA. 
Table 2. Experimental Values of the Box-Behnken Design

\begin{tabular}{lcccc}
\hline Runs & $\mathbf{X}_{\mathbf{1}}$ & $\mathbf{X}_{\mathbf{2}}$ & $\mathbf{X}_{\mathbf{3}}$ & Omethoate degradation rate (\%) \\
\hline 1 & -1 & -1 & 0 & 68.45 \\
2 & -1 & 1 & 0 & 70.34 \\
3 & 1 & -1 & 0 & 66.65 \\
4 & 1 & 1 & 0 & 68.22 \\
5 & 0 & -1 & -1 & 67.10 \\
6 & 0 & -1 & 1 & 63.76 \\
7 & 0 & 1 & -1 & 69.57 \\
8 & 0 & 1 & 1 & 68.65 \\
9 & -1 & 0 & -1 & 69.44 \\
10 & 1 & 0 & -1 & 67.39 \\
11 & -1 & 0 & 1 & 68.89 \\
12 & 1 & 0 & 1 & 64.21 \\
13 & 0 & 0 & 0 & 77.35 \\
14 & 0 & 0 & 0 & 77.46 \\
15 & 0 & 0 & 0 & 77.38 \\
\hline
\end{tabular}

By applying multiple regression analysis of the experimental data, the results were fit with a second-order polynomial equation. Thus, a mathematical regression model for omethoate degradation using the coded factors was given as:

$$
\begin{gathered}
Y=77.3966-1.33125 \mathrm{X}_{1}+1.3525 \mathrm{X}_{2}-0.99875 \mathrm{X}_{3} \\
-4.384583 \mathrm{X}_{1} \mathrm{X}_{1}-4.597083 \mathrm{X}_{2} \mathrm{X}_{2}-5.529583 \mathrm{X}_{3} \mathrm{X}_{3}
\end{gathered}
$$

The determination coefficient $\left(R^{2}\right)$ was 0.9892 , which indicating the model had extremely good fitting degree. ANOVA results showed that the linear effects $\left(\mathrm{X}_{1}\right.$ and $\left.\mathrm{X}_{2}\right)$ and the quadratic effects $\left(\mathrm{X}_{1}{ }^{2}\right.$, $\mathrm{X}_{2}{ }^{2}$ and $\left.\mathrm{X}_{3}{ }^{2}\right)$ were highly significant $(\mathrm{P}<0.01)$, the linear effects of $\mathrm{X}_{3}$ were significant $(\mathrm{P}<0.05)$, while the interaction effects $\left(\mathrm{X}_{1} \mathrm{X}_{2}, \mathrm{X}_{1} \mathrm{X}_{3}\right.$, and $\left.\mathrm{X}_{2} \mathrm{X}_{3}\right)$ were insignificant.

The optimum conditions for omethoate degradation were calcu- lated with the SAS software as $\mathrm{X}_{1}=-0.15, \mathrm{X}_{2}=0.14, \mathrm{X}_{3}=-0.07$, which accordingly the optimum composition of nutrition in medium were glucose of $1.455 \mathrm{~g} / \mathrm{L}, \mathrm{NH}_{4} \mathrm{NO}_{3}$ of $0.535 \mathrm{~g} / \mathrm{L}, \mathrm{KH}_{2} \mathrm{PO}_{4}$ of 0.965 g/L. In this condition, the mass ratio of C:N:P was 3:1:1. The omethoate degradation rate was predicted as $77.40 \%$. To confirm the validity of the statistical experimental strategies, additional confirmation experiments were done under the optimal culture condition of glucose $1.46 \mathrm{~g} / \mathrm{L}, \mathrm{NH}_{4} \mathrm{NO}_{3} 0.54 \mathrm{~g} / \mathrm{L}, \mathrm{KH}_{2} \mathrm{PO}_{4} 0.97 \mathrm{~g} / \mathrm{L}$. Result showed that omethoate degradation rate reached $77.16 \%$, which was much close to the predicted value.

\subsection{Effect of Omethoate Concentration and Degradation Kinetics}

The effect of omethoate concentration on degradation effectivity by Bacillus sp. YB-10 was shown in Fig. 4(a). It is clear that high concentration of the omethoate would restrain the degradation process. This might be because that high concentration of omethoate could have toxicity to the Bacillus sp. YB-10, which subsequently restrain the bacteria growth and affect the metabolic activity. Also, the intermediate which was produced during the omethoate degradation process might restrain the activity of degrading enzymes. As the omethoate concentration rose, the intermediate increased and more degrading enzymes would be disabled; therefore, the degradation ability was decreased. These were also the reasons of slight increase in omethoate degradation after $5 \mathrm{~d}$. In addition, Fig. 4(a) revealed that the degradation rate increased slowly with time at high omethoate concentration, which might also due to the toxicity of omethoate. This was consistent with Meng et al.'s [8] study. Therefore, the degradation time was determined as $5 \mathrm{~d}$.

As the results of omethoate degradation kinetics shown in Fig. 4(b), it was clear that the first-order model gave a good fit under different initial omethoate concentrations. The regression coefficients $R^{2}$ were larger than 0.95 . Therefore, it concluded that the kinetics of omethoate biodegradation by Bacillus sp. YB-10 could be described by a first-order reaction model under test conditions. When the initial omethoate concentrations were 200, 500, (1,000), (2,000) and 5,000 $\mathrm{mg} / \mathrm{L}$, the biodegradation half-lifes
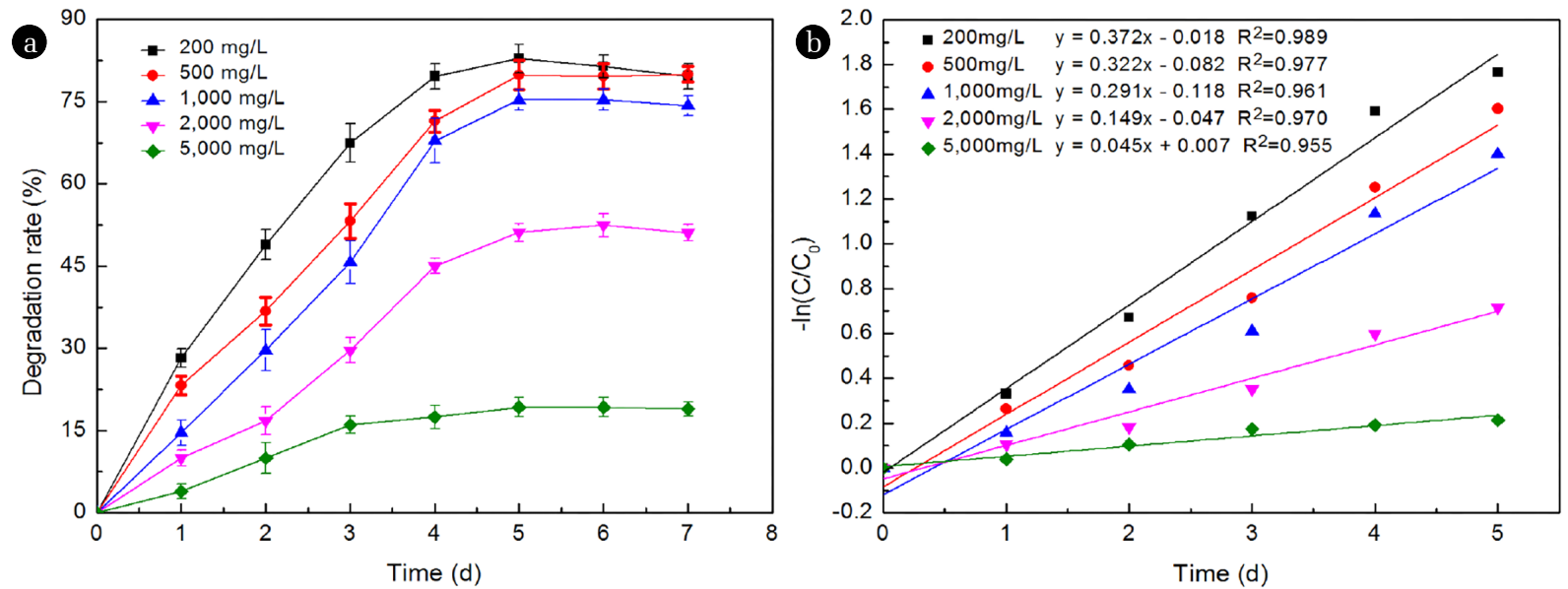

Fig. 4. The effect of omethoate concentrations on degradation rate and kinetics of omethoate degradation by Bacillus sp.YB-10. (pH = 7.0, $30^{\circ} \mathrm{C}$, initial bacteria concentration: $0.25 \%$, rotation speed: $150 \mathrm{r} / \mathrm{min}$ ) 


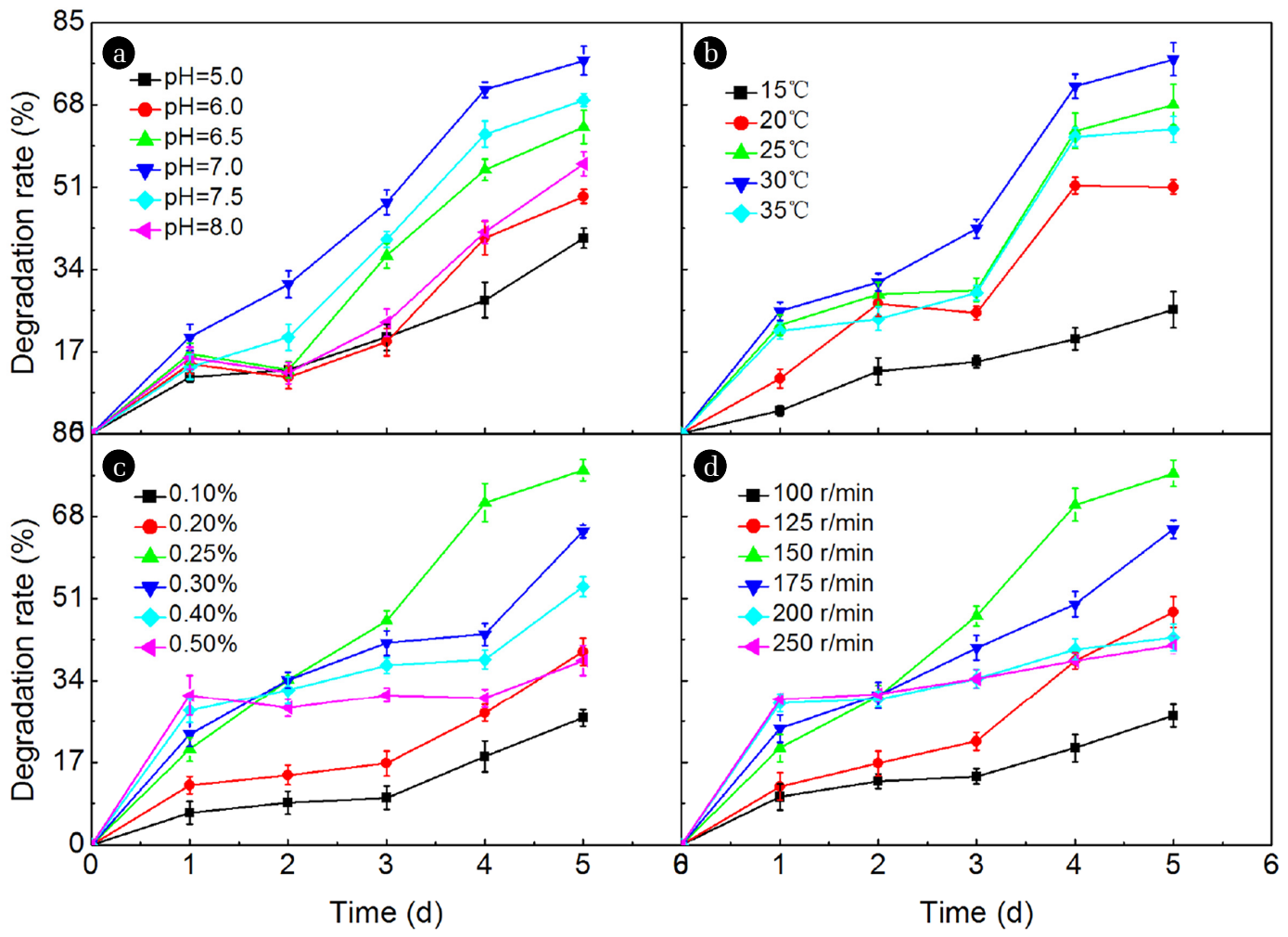

Fig. 5. The effect of different conditions on omethoate degradation by Bacillus sp.YB-10. (a) $\mathrm{pH}\left(30^{\circ} \mathrm{C}\right.$, initial bacteria concentration: $0.25 \%$, rotation speed: $150 \mathrm{r} / \mathrm{min})$; (b) temperature $(\mathrm{pH}=7.0$, initial bacteria concentration: $0.25 \%$, rotation speed: $150 \mathrm{r} / \mathrm{min})$; (c) initial bacteria concentration $\left(\mathrm{pH}=7.0,30^{\circ} \mathrm{C}\right.$, rotation speed: $\left.150 \mathrm{r} / \mathrm{min}\right)$; $(\mathrm{d})$ rotation speed $\left(\mathrm{pH}=7.0,30^{\circ} \mathrm{C}\right.$, initial bacteria concentration: $\left.0.25 \%\right)$.

$\left(\mathrm{t}_{1 / 2}\right)$ were $1.86,2.15,2.38,4.65$ and $15.40 \mathrm{~d}$, respectively. This result also showed that high concentration of omethoate could constraint the biodegradation ability. Tao et al. [3] reported that the biodegradation half-life was $5.24 \mathrm{~d}$ by Aspergillus niger when degrading $1,000 \mathrm{mg} / \mathrm{L}$ of omethoate. In contrast, the biodegradation half-life in this study was much lower under same initial omethoate concentration. This demonstrated that the biodegradation ability of Bacillus sp. YB-10 was much stronger than Aspergillus niger. In addition, in view of the strong omethoate degradation ability Bacillus sp. YB-10, we inferred that the strain could be induced to produce an enzyme which was able to cleave the P-S bond in omethoate. However, further study is needed.

\subsection{Biodegradation Conditions of Omethoate}

\subsubsection{Effect of initial $\mathrm{pH}$}

As omethoate could be hydrolyzed and lost efficacy under alkaline condition, we investigated the effect of $\mathrm{pH} 5.0-8.0$ at a temperature of $30^{\circ} \mathrm{C}$, initial bacteria concentration of $0.25 \%$, rotation speed of $150 \mathrm{r} / \mathrm{min}$. Results were shown in Fig. 5(a). As revealed in Fig. 5(a), Bacillus sp. YB-10 could degrade omethoate at $\mathrm{pH}$ of 5-8. The best degradation effectivity was obtained at $\mathrm{pH} 7.0$, under which the degradation rate increased fastly with time $(77.11 \%$ at $5 \mathrm{~d}$ ). Both the acid and alkaline conditions could restrain the growth of Bacillus sp. YB-10. Omethoate degradation rates were less than $40 \%$ when $\mathrm{pH}$ was 5.0 during the degradation process. When the $\mathrm{pH}$ was 8.0, the degradation rates were also decreased
(56.11\% at $5 \mathrm{~d}$ ). In this study, the best $\mathrm{pH}$ for degrading omethoate was determined as 7.0.

\subsubsection{Effect of temperature}

The effects of temperature were investigated at a $\mathrm{pH}$ of 7.0, initial bacteria concenrtation of $0.25 \%$, rotation speed of $150 \mathrm{r} / \mathrm{min}$. As revealed in Fig. 5(b), there was obvious effect of temperature on omethoate degradation. When the temperature increased from $15^{\circ} \mathrm{C}$ to $30^{\circ} \mathrm{C}$, the degradation rate increased. The highest degradation rate obtained at temperature of $30^{\circ} \mathrm{C}$. Actually, it was biochemical reactions by enzymes during the organic biodegradation process. Higher temperature could induce the inactivation of enzymatic; whereas lower temperature could restrain the effectivity of enzymatic. Also, the growth of bacteria was affected by temperature directly. The bacterial grew well at optimal temperature of $30^{\circ} \mathrm{C}$, which accordingly increased the activity of organophosphates degrading enzymes.

\subsubsection{Effect of initial bacteria concentration}

The effects of the initial bacteria concenrtations of Bacillus sp. YB-10 were investigated at a $\mathrm{pH}$ of 7.0 , temperature of $30^{\circ} \mathrm{C}$, rotation speed of $150 \mathrm{r} / \mathrm{min}$. Results were shown in Fig. 5(c). The degradation rate increased with initial bacteria concentration when it was < $0.25 \%$. Fig. 5(c) also reveals that the higher of initial bacteria concentration, the better of degradation rate at the first day. However, the degradation rate increased slowly in the following days when the initial bacteria was $>0.25 \%$. These results suggested that the 
degradation ability did not increase with initial bacteria concentration. At lower bacteria concentrations, there were not enough biomass for omethoate degrading. However, as the initial bacteria concentration was too high, the bacteria were in poor nutrient. Accordingly there were competition between bacteria, which could also restrain the bacteria growth [38]. In this study, the optimal initial bacteria concentration was $0.25 \%$.

\subsubsection{Effect of rotation speed}

Fig. 5(d) shows the effects of different rotation speeds on the omethoate degradation rate at a $\mathrm{pH}$ of 7.0 , temperature of $30^{\circ} \mathrm{C}$, initial bacteria concentration of $0.25 \%$. The degradation rate increased obviously as the rotation speed increased from 100 to $150 \mathrm{r} / \mathrm{min}$. When the rotation speeds were higher than $150 \mathrm{r} / \mathrm{min}$, all the degradation rates became lower except the first day. Lower rotation speed could not provide enough dissolved oxygen for the bacteria growth. On the other hand, the bacteria could gather together at lower rotation speed, which restrained the contact with medium. All these factors restrained the growth of bacterial. Under higher rotation speed, the mechanical impact could destroy the normal growth of bacteria. In the current study, the optimal rotation speed was $150 \mathrm{r} / \mathrm{min}$, under which the maximum degradation rate reached $77.24 \%$ at $5 \mathrm{~d}$. The degradation effectivity was consistent with other's study, in which the omethoate degradation rate was $77.59 \%$ by Aspergillus niger [3].

In this study, the degradation ability of Bacillus sp. YB-10 was based on a pure microbia culture. However, the conditions of environment were very complex. When the bacteria ware used for bioremediation or bioaugmentation, the influence of nature conditions must be considered. Nonetheless, the results of this study could provide useful information for the biodegradation of omethoate in the environment.

\section{Conclusions}

Bacillus sp. YB-10 was used for degrading omethoate in this study. The culture conditions and degradation characteristics were investigated. It was conclude that the Bacillus sp. YB-10 could degrade omethoate through co-metabolism. The most appropriate nutrition ration was glucose of $1.455 \mathrm{~g} / \mathrm{L}, \mathrm{NH}_{4} \mathrm{NO}_{3}$ of $0.535 \mathrm{~g} / \mathrm{L}$, and $\mathrm{KH}_{2} \mathrm{PO}_{4}$ of $0.965 \mathrm{~g} / \mathrm{L}$ when degrading $1,000 \mathrm{mg} / \mathrm{L}$ of omethoate. The kinetics for omethoate degradation could be described by a first-order rate equation. The optimal degradation conditions were $\mathrm{pH}$ of 7.0 , temperature of $30^{\circ} \mathrm{C}$, initial bacteria concentration of $0.25 \%$, rotational speed of $150 \mathrm{r} / \mathrm{min}$. Under the optimal conditions, the degradation rate by the Bacillus sp. YB-10 within $5 \mathrm{~d}$ reached $77.24 \%$ when the omethoate concentration was $1,000 \mathrm{mg} / \mathrm{L}$. The results of this work may provide useful information for the biodegradation of omethoate in wastewater, soil and groundwater.

\section{Acknowledgment}

This work was supported by the National Natural Science Foundation of China (No. 31070048) and Scientific and Technological Innovation Programs of Higher Education
Institutions in Shanxi (2019L0087).

\section{Author Contributions}

R.L. (Associate professor) planned the study, wrote and revised the manuscript. J.W. (Associate professor) and S.L. (Engineer) conducted the experiments.

\section{References}

1. Arthur AL, Babineau M, Umina PA. Insecticide Responses in the Collembola Pest, Sminthurus viridis (Collembola: Sminthuridae), in Australia. J. Econ. Entomol. 2020;113:1940-1945.

2. Zhang L, Li B, Meng X, et al. Degradation of four organophosphorous pesticides catalyzed by chitosan-metal coordination complexes. Environ. Sci. Pollut. R. 2015;22:15104-15112.

3. Tao Y, Wang Y, Yan S, et al. Optimization of omethoate degradation conditions and a kinetics model. Int. Biodeter. Biodegr. 2008;62:239-243.

4. Huo D, Jiang S, Qin Z, et al. Omethoate induces pharyngeal cancer cell proliferation and G1/S cell cycle progression by activation of Akt/GSK-3ß/cyclin D1 signaling pathway. Toxicology 2019;427:152298.

5. Bai Y, Chen J, Mu H, et al. Reduction of Dichlorvos and Omethoate Residues by O2 Plasma Treatment. J. Agr. Food Chem. 2009;57:6238-6245.

6. Li C, Ma Y, Mi Z, et al. Screening for Lactobacillus plantarum Strains That Possess Organophosphorus Pesticide-Degrading Activity and Metabolomic Analysis of Phorate Degradation. Front Microbiol. 2018;9:1-23.

7. Singh BK, Walker A, Morgan JAW, et al. Biodegradation of Chlorpyrifos by Enterobacter Strain B-14 and Its Use in Bioremediation of Contaminated Soils. Appl. Environ. Microb. 2004;70:4855-4863.

8. Meng C, Chngchun S, Guo Y, et al. Study on characteristics of biocometabolic removal of omethoate by the Aspergillus spp. Water Res. 2004;38:1139-1146.

9. Zhang L, Rao Z, Ji H. NIR Hyperspectral Imaging Technology Combined with Multivariate Methods to Study the Residues of Different Concentrations of Omethoate on Wheat Grain Surface. Sensors 2019;19:3147.

10. Lazarevi Pašti TD, Pašti IA, Joki B, et al. Heteroatom-doped mesoporous carbons as efficient adsorbents for removal of dimethoate and omethoate from water. Rsc. Adv. 2016;6:62128-62139.

11. Zhao D, Wang J, Zhao X, et al. TiO2/NaY Composite as Photocatalyst for Degradation of Omethoate. Chem. Res. Chinese U. 2009;25:543-549.

12. Qiang Z, Ling W, Tian F. Kinetics and mechanism for omethoate degradation by catalytic ozonation with Fe(III)-loaded activated carbon in water. Chemosphere 2013;90:1966-1972.

13. Zhou R, Zhou R, Yu F, et al. Removal of organophosphorus pesticide residues from Lycium barbarum by gas phase surface discharge plasma. Chem. Eng. J .2018;342:401-409.

14. Zheng L, Pi F, Wang Y, et al. Photocatalytic degradation of Acephate, Omethoate, and Methyl parathion by $\mathrm{Fe}_{3} \mathrm{O}_{4} @ \mathrm{SiO}_{2}$ 
$@ \mathrm{mTiO}_{2}$ nanomicrospheres. J. Hazard. Mater. 2016;315:11-22.

15. Xiao Z, Lishuang Wang L, Zhang Y, et al. Synthesis and characterization of a novel rice bran protein-cerium complex for the removal of organophosphorus pesticide residues from wastewater. Food Chem. 2020;320:126604.

16. Zinatloo-Ajabshir S, Morassaei MS, Amiri O, et al. Green synthesis of dysprosium stannate nanoparticles using Ficus carica extract as photocatalyst for the degradation of organic pollutants under visible irradiation. Ceram. Int. 2020;46:6095-6107.

17. Zinatloo-Ajabshir S, Salehi Z, Salavati-Niasari M. Green synthesis and characterization of $\mathrm{Dy}_{2} \mathrm{Ce}_{2} \mathrm{O}_{7}$ nanostructures using Ananas comosus with high visible-light photocatalytic activity of organic contaminants. J. Alloy. Compd. 2018;763:314-321.

18. Zinatloo-Ajabshir S, Salehi Z, Salavati-Niasari M. Green synthesis of $\mathrm{Dy}_{2} \mathrm{Ce}_{2} \mathrm{O}_{7}$ ceramic nanostructures using juice of Punica granatum and their efficient application as photocatalytic degradation of organic contaminants under visible light. Ceram. Int. 2018;44:3873-3883.

19. Zinatloo-Ajabshir S, Baladi M, Amiri O, Salavati-Niasari M. Sonochemical synthesis and characterization of silver tungstate nanostructures as visible-light-driven photocatalyst for waste-water treatment. Sep. Purif. Technol. 2020;248:117062.

20. Belal EB, Shalaby ME, El-Gremi SM, et al. Biodegradation of Organochlorine Pesticides by Paenibacillus sp. Strain. Environ. Eng. Sci. 2018;35:1194-1205.

21. Cheng S, Vidakovic-Cifrek Ž, Grosse W, et al. Xenobiotics removal from polluted water by a multifunctional constructed wetland. Chemosphere 2002;48:415-418.

22. Singh S, Singh DK. Utilization of monocrotophos as phosphorus source by Pseudomonas aeruginosa F10B and Clavibacter michiganense subsp. insidiosum SBL 11. Can. J. Microbiol. 2003;49: 101-109.

23. Deng S, Chen Y, Wang D, et al. Rapid biodegradation of organophosphorus pesticides by Stenotrophomonas sp. G1. J. Hazard. Mater. 2015;297:17-24.

24. Carranza CS, Barberis CL, Chiacchiera SM, et al. Assessment of growth of Aspergillus spp. from agricultural soils in the presence of glyphosate. Rev. Argent. Microbiol. 2017;49:384-393.

25. Sidhu GK, Singh S, Kumar V, et al. Toxicity, monitoring and biodegradation of organophosphate pesticides: A review. Crit. Rev. Env. Sci. Tec. 2019;49:1135-1187.
26. Zhao R, Bao H, Liu Y. Isolation and Characterization of Penicillium oxalicum ZHJ6 for Biodegradation of Methamidophos. Agric. Sci. In China 2010;9:695-703.

27. Zhang J, Yin J, Hang B, et al. Cloning of a Novel Arylamidase Gene from Paracoccus sp. Strain FLN-7 That Hydrolyzes Amide Pesticides. Appl. Environ. Microb. 2012;78:4848-4855.

28. Liu F, Hong M, Liu D, et al. Biodegradation of methyl parathion by Acinetobacter radioresistens USTB-04. J. Environ. Sci. (China) 2007;19:1257-1260.

29. Li F, Yu Z, He S. Agricultural microbiologi cal experimental technique: Chinese Agriculture Press; 1996.p.34-36.

30. Fan X, Li G, Shen P. Microbiology Experiment: Higher Education Press; 1988.p.75-78.

31. Srinivasa PC, Ravi R, Tharanathan RN. Effect of storage conditions on the tensile properties of eco-friendly chitosan films by response surface methodology. J. Food. Eng. 2007;80:184-189.

32. Yang Y, Lin E, Huang S. Heterotrophic nitrogen removal in Bacillus sp. K5: involvement of a novel hydroxylamine oxidase. Water Sci. Technol. 2017;76:3461-3467.

33. Meyer H, Weidmann H, Mäder U, et al. A time resolved metabolomics study: the influence of different carbon sources during growth and starvation of Bacillus subtilis. Mol. Biosyst. 2014;10:1812-1823.

34. Ren H, Liu B, Ma C, et al. A new lipid-rich microalga Scenedesmus sp. strain R-16 isolated using Nile red staining: effects of carbon and nitrogen sources and initial $\mathrm{pH}$ on the biomass and lipid production. Biotechnol. Biofuels. 2013;6:143.

35. Mohanrasu K, Rao RGR, Dinesh GH, et al. Optimization of media components and culture conditions for polyhydroxyalkanoates production by Bacillus megaterium. Fuel 2020;271:117522.

36. Yashchuk O, Hermida ÉB. Influence of Culture Conditions on Poly-3-Hydroxybutyrate Production by a Newly Isolated Bacillus cereus Y23. Clean-Soil, Air, Water 2020;48:1900415.

37. Prakash S, Rajeswari K, Divya P, et al. Optimization and production of curdlan gum using Bacillus cereus pr3 isolated from rhizosphere of leguminous plant. Prep. Biochem. Biotech. 2018;48(5):408-418.

38. Li R, Wang J, Li H. Isolation and characterization of organic matter-degrading bacteria from coking wastewater treatment plant. Water. Sci. Technol. 2018;78:1517-1524. 